\title{
EVALUATION OF SALT WATER EFFECT ON THE PHYSICAL PROPERTIES AND COMPACTION CHARACTERISTICS OF EXPANSIVE SOIL
}

\author{
Adel El Kady \\ PH.D. Student, Department of Civil Engineering, \\ Al-Azhar University, Cairo, Egypt. \\ Mahmoud A. Bakr \\ Assistant Professor, Department of Civil Engineering, \\ Al-Azhar University, Cairo, Egypt. \\ Samir A. Gad \\ Professor, Department of Civil Engineering, \\ Al-Azhar University, Cairo, Egypt.
}

\begin{abstract}
Expansive soils pose a significant hazard to civil engineering structures due to its high swelling and shrinkage potential. There are many techniques available to reduce the effect of volume change of expansive soil due to change in water content within the soil mass. Soil stabilization by mixing various chemical additives has been proved to be effective alternative solution to overcome the undesirable swell. The objective of present study is to determine and evaluate the effect of addition of chloride salts on expansive soil in term of change in index properties and swelling characteristics. In this study, an experimental program developed to investigate the effect of salt water on the engineering properties of high swelling clays. The laboratory tests were carried out in the soil mechanics laboratory of Al Azhar University and central laboratories of Arab Contractors. The materials used in this research were silty clay obtained from Bait El Watan project, western of Suez road in New Cairo city, tap water as well as saline water, which is obtained from mixing of salts and distilled water at various concentrations $(5,10,20,30,50$ and $60 \%)$ as an effective chemical stabilizer in expansive soils. However, the results showed a remarkable decrease in liquid limit by 47.8 percent. Plastic limit also showed a continuous decrease with increasing salt concentration to reach $6.2 \%$ decrease at $60 \%$ salt concentration. Compaction properties also significantly improved in presence of salty water as the maximum dry density increased from $17.83 \mathrm{kn} / \mathrm{m} 3$ to $18.95 \mathrm{kn} / \mathrm{m} 3$ at salt concentration of $60 \%$, with a corresponding decrease from $15.6 \%$ to $12 \%$ in optimum moisture content.
\end{abstract}


Free swell index reached a maximum decrease of $21.7 \%$ at a salt concentration of $30 \%$, as it decreased from $66.65 \%$ to $56.8 \%$. Results of Oedometer test also revealed an improve of swelling properties of expansive clay soil expressed by a decrease in swelling heave from 5.61 for samples mixed with fresh water to $4.3 \mathrm{~mm}$ when mixed with $30 \%$ salt concentration with a rate of reduction $23.4 \%$.

Keywords: Expansive Soil, Salt Water effect, Geotechnical characteristics, Laboratory Tests.

Cite this Article: Adel El Kady, Mahmoud A. Bakr and Samir A. Gad, Evaluation of Salt Water Effect on the Physical Properties and Compaction Characteristics of Expansive Soil, International Journal of Civil Engineering and Technology (IJCIET), 11(11), 2020, pp. 49-64.

https://iaeme.com/Home/issue/IJCIET?Volume=11\&Issue=11

\section{INTRODUCTION}

Partially saturated clayey soils which show excessive volume changes under applied pressure due to a rise in their water contents are classified as expansive soil. Documented evidence of the existence of and associated with expansive clay soils is world-wide. Structure constructed on expansive soils induce heave from a variety of reasons. The subsequent increase in soil moisture content has caused heave in expansive soils. Environmental conditions of a particular area in which expansive soils are located play an important role in the behavior of such soils. The frequency of rainfall, rate of evaporation, and activity of the clay are parameters in the eventual heave of expansive soils, Hegazi (1993). Chemical stabilization involves mixing or injecting soil with chemically active compounds such as cement, lime, fly ash, calcium or sodium chloride or with viscoelastic materials such as bitumen Soils with high clay content have a tendency to swell at high moisture contents (Chen 1981), thus causing cracking and break up of pavements, railways, highways, embankments, roadways, foundations and reservoir linings Erdal Cokca (1999).Chemical stabilization has been increasingly adopted for improving the properties of expansive soils in recent years.

This paper highlights on the effect of chloride salts on expansive soil in term of change in index properties and swelling characteristics. The use of chloride salts to stabilize expansive clays has been investigated by many researchers.as reported in available literature. Some of these researched are reviewed in this section.

G.R.Qtoko, (2014) studied the effect of salt water on the physical properties, compaction characteristics and unconfined compressive strength of a clay, clayey sand and base course. Results have shown that addition of salty water has great improvement in their Atterberg limits, compaction characteristics and unconfined compression strength. The effect of seawater on swelling characteristics of montmorillonite clay has been investigated by Mohie Eldin Elmashad and Alaa A. Ata, (2014). Their experimental results indicated that for clays containing montmorillonite mineral percentage higher than $72 \%$ and having a liquid limit higher than $140 \%$ when mixed with distilled water show that the liquid limit and the swelling potential are significantly reduced if saltwater is used in mixing. Di Maio, C., and G. b. Fenelli ,1994 and Y. Yukselen-Aksoy, A. Kaya, A. O* ren, 2008 have published studies on the variations in behavior of clayey soils upon mixing with fluids other than distilled water2.Also Kumar, et al., (2015) studied the effect of Salinity on geotechnical properties of expansive soils carried out using inorganic salt solutions such as $\mathrm{NaCl}$ at three types of concentrations $(0.001$, $0.01,0.05)$, the results show that the liquid limit, plastic limit, free swell index, optimum moisture content decreases with increase in the salt solutions and the maximum dry density and unconfined compressive strength increases with increase in the salt solutions. Ramadas, et al., 
(2012) studied the effect of various percentage of calcium chloride such as $0.5 \%, 1.0 \%, 1.5 \%$ and $2 \%$ on the engineering properties of three expansive soils and the result shows reduced plasticity and increased the strength of the soils3.The effects of salt solution on shear strength of soil have been investigated by Chattopadhyay, 1972;Alamdar, 1999; Tiwari et al., 2005; Ayininuola et al., 2009;Naeini and Jahanfar, 2011 and Siddiqua et al., 2011.In these studies, shear strength of soil has increased as concentration of water increased. Yousry M. Mowafy et al., (2015) have investigated three techniques to reduce the swelling properties of expansive soil. Their results showed that the presence of sodium chloride in the pore fluid caused a decrease in swelling and swelling pressure. Therefore, the injection of a salt solution into swellsusceptible soils could be a possible method of overcoming this problem, if the soil permeability is sufficiently high.Magdi M. E. Zumrawi et al., (2016) studied the effect of some chloride salts on consistency and swelling characteristics of expansive Soil. The results inferred were the addition of chloride salt to the expansive clay decreased the liquid limit and the plasticity index of the treated soil. The reduction in the plasticity index values of the treated soil with addition of $15 \%$ salt is more than $78 \%$ of the initial value. A significant decrease in the swelling characteristics of the stabilized expansive clay with addition of chloride salts.Abood et al. studied the effect of adding three chloride salts $(\mathrm{NaCl}, \mathrm{MgCl} 2, \mathrm{CaCl} 2)$ on the properties of silty clay soil. Their findings showed that the addition of each salt decreased the liquid limit and increased the plastic limit and accordingly reduced the plasticity index of the soil. The maximum dry density and the compressive strength increased while the optimum moisture content decreased with the increased in salt percentage. Amar Prit Singh Arora et al., (2018). found that Atterberg's Limits decreases in presence of sea water. Further, plasticity index also decreases to a great extent due increase in salinity in water. On addition, maximum dry density of clayey soil increases in presence of sea water while optimum moisture content of clayey soil decreases in presence of sea water comparing with the results obtained from tap water. The effect of saline water on geotechnical properties of fine-grained soil has been evaluated by Rassoul Ajalloeian et al., (2013). The findings conducted that Atterberg limits, compression index, swelling index, coefficient of volume compressibility (mv) and coefficient of compressibility (av) have decreased and consolidation of coefficient and shear strength parameters have increased as water salinity increased. The main reason of these changes have been attributed to increasing attractive force between soil particles, establishing bonding between them and forming salt crystals in pores soil and role playing as cement. Alamdar, 1991; Mahasneh, 2004; Yukselen-Aksoy et al., 2008; Mansour et al, 2008; Arasan and Yetimoglu, 2008; and Shariatmadari et al, 2011 have studied the effect of salt solutions on the consistency limits of soil. The results have shown the liquid limit and plastic limit of soil decrease as the salinity of pore fluid increases. The test results performed by Yukselen-Aksoy et al., (2008) show seawater has limited effect on the compressibility of clayey soils with liquid limit less than $110 \%$. In clayey soils with liquid limit more than $110 \%$ (Na-bentonites), seawater effect becomes significant.Dr. P. D. Arumairaj and A. Sivajothi, (2011). Carried out a study to investigate the effect of sea water on expansive soils. The test results were analyzed and conducted that treatment with sea water causes reduction in liquid limit, plastic limit, plasticity index, free swell index and swelling pressure of the clay minerals. The coefficient of consolidation and California bearing ratio increased upon treatment with sea water.Durotoye et al., (2016). Found that addition of $1.5 \%$ sodium chloride to the soil, maximum reduction percentage of $60.42 \%$ on liquid limit, $42.86 \%$ on plastic limit, $71.26 \%$ on plasticity index, $83.43 \%$ on free swell index and $28.57 \%$ on optimum moisture content. Addition of $1.5 \%$ sodium chloride to the soil, maximum percentage increase of 11.38 , on Maximum dry density, $31.78 \%$ on unsoaked CBR), $257.67 \%$ on soaked CBR, and $26.98 \%$ on unconfined compressive strength. 
The previous experiences reviewed had proven that chloride salts have positive impacts on the engineering properties of high swelling clays. Their findings confirmed that the effect of added chloride salt not only depends upon the soil property but also on the added salt quantity.

\section{EXPERIMENTAL PROGRAM}

To study the effect of salt water on the geotechnical properties of fine-grained soil, the basic characteristics of the soil were measured. Then laboratory tests including Atterberg limits, standard compaction, swelling index and consolidation tests were carried out for fresh water and different salt concentration according to procedures referred to in this section:

\subsection{Materials}

The materials used in this research were silty clay obtained from Bait El Watan project, western of Suez Road in New Cairo city, tap water as well as saline water, which is obtained from mixing of salts and distilled water at various concentrations as an effective chemical stabilizer in expansive soils. Selected samples were oven dried and pulverized to be in powder form. The dry samples were prepared by compacting soil powder to reach a density of about $20.2 \mathrm{kN} / \mathrm{m} 3$. The prepared samples were with diameter of $63 \mathrm{~mm}$ and height of $16 \mathrm{~mm}$.

The soil sample kept for stabilization was mixed with sodium chloride solutions of varying concentrations, prepared by dissolving common salt in distilled water. The concentrations prepared are: fresh water, 5\%, 10\%, 20\%, 30\%, 50\% and $60 \%$, and various engineering properties including, natural moisture content, Atterberg limits (liquid limit, plastic limit and shrinkage Limit), specific gravity, free swell index, proctor compaction and swelling behavior were carried out .The overall testing program was conducted in two phases. In the first phase the index properties and engineering properties of the selected soil samples including chemical, physical and mechanical properties were studied by conducting laboratory experiments. In the second phase, soils were mixed with fresh water, $5 \%, 10 \%, 30 \%, 50 \%$ and $60 \%$ of $\mathrm{NaCl}$ by dry weight of soil. The tests were performed according to British standard methods of test for soil for civil engineering purposes (BS 1377: Part 1-9, 1990) and the test determination of the various properties, discussed herewith.

\subsection{Material Testing}

\subsubsection{Chemical Composition of Expansive Soil Samples:}

In order to identify the clay minerals in the soil, $x$-ray fluorescence (XRF), X-ray diffraction test (XRD) and Differential thermal analysis (DTA) were carried out on soil passing $75 \mathrm{~mm}$ (no. 200) sieve. The mineralogical composition of the tested soil was found by X-ray, and the results are given in Table 1.In this method, water was added to soil until to reach the liquid limit. After soil and water exposure during 24 hours, saturated extract was taken by vacuum pump. Then cations concentration of $\mathrm{Ca} 2+, \mathrm{Mg} 2+, \mathrm{Na}+$ and $\mathrm{k}+$ were determined in saturated extracts.

Table .1. XRF analysis of natural fine grained soil

\begin{tabular}{|l|l|l|l|l|l|l|l|l|l|l|l|l|l|l|l|l|l|l|l|}
\hline & $\mathrm{SiO} 2$ & $\mathrm{AL} 2 \mathrm{O} 3$ & $\mathrm{Fe} 2 \mathrm{O} 3$ & $\mathrm{CaO}$ & $\mathrm{MgO}$ & $\mathrm{Na} 2 \mathrm{O}$ & $\mathrm{K} 2 \mathrm{O}$ & $\mathrm{SO} 3$ & $\mathrm{TiO} 2$ & $\mathrm{P} 2 \mathrm{O} 5$ & $\mathrm{MNO}$ & $\mathrm{ZrO} 2$ & $\mathrm{SrO}$ & $\mathrm{ZnO}$ & $\mathrm{Cr} 2 \mathrm{O} 3$ & $\mathrm{BaO}$ & $\mathrm{CL}$ & $\mathrm{L} . \mathrm{O} . \mathrm{L}$ & $\mathrm{Total}$ \\
\hline Natural Soil & 52.9 & 17.7 & 10.6 & 2.09 & 1.5 & 0.91 & 1.95 & 1.38 & 1.53 & 0.22 & - & 0.08 & 0.05 & 0.04 & 0.04 & 0.04 & 0.55 & 8.41 & 99.99 \\
\hline
\end{tabular}

X-ray diffraction and Differential Thermal Analysis tests for clay soil samples were carried out to investigate different types of clay and non-clay minerals. The charts of X-ray diffraction and differential thermal analysis for natural soil samples are presented in Figure 1and 2. 


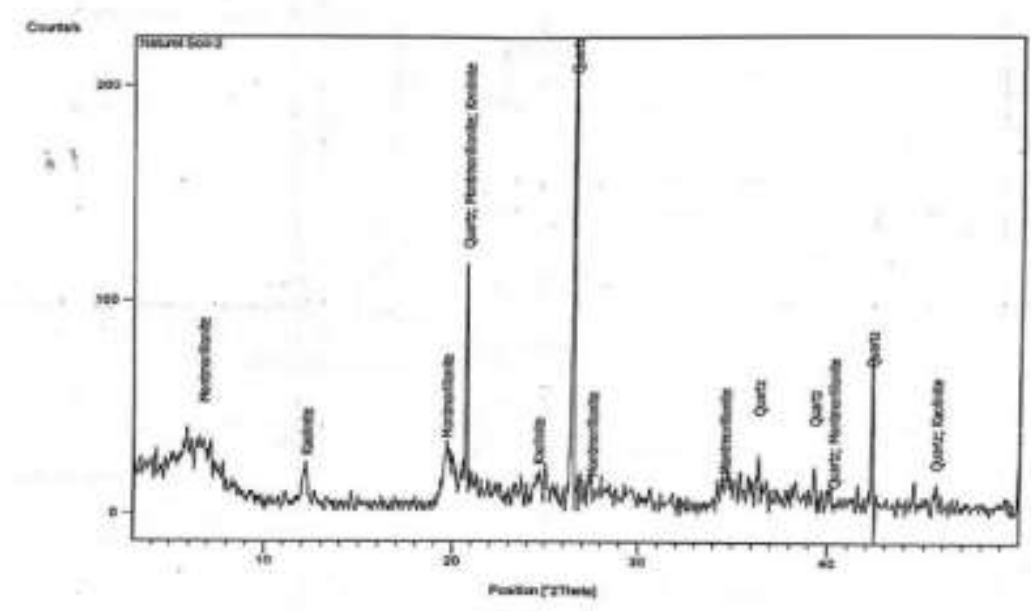

Figure 1 X-Ray Diffraction for Untreated Soil

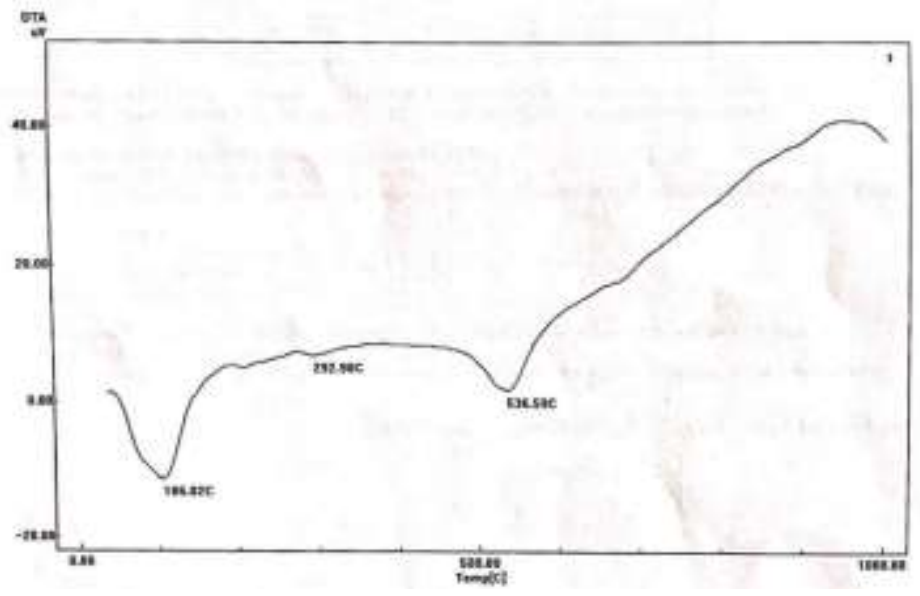

Figure 2 Differential thermal analysis for untreated soil

\subsubsection{Geotechnical Properties}

\subsubsection{Atterberg Limits:}

The Atterberg Limits are the primary constituents among the geotechnical properties. These liquid limits and plastic limits are determined by performing the Casagrande apparatus and palming respectively. The tests were performed according to IS 2720-Part 15, (1985) on soil passing $425 \mu$ sieve. For saline water, this test was performed at different concentrations.

\subsubsection{Specific Gravity:}

The Specific gravity $\left(\mathrm{G}_{\mathrm{s}}\right)$ of the soil has been determined by exploited some density bottle and pycnometer as per the guidelines provided by IS 2720-Part 3, (1980). The average value has been taken from the three trials was obtained.

\subsubsection{Standard Proctor Compaction Test:}

The soil sample was oven dried at $110^{\circ}$ for about 24 hours. Later, as per international standards, the soil is mixed with fresh water and various concentrations of salt in weight and then this mix has been compacted in three equal layers with each set of experiments with increasing the water content. Later, based on the compaction curves plotted for the different mix, optimum 
moisture content (OMC) and maximum dry density (MDD) for each test specimens were obtained.

\subsubsection{Free Swell Index}

Free swell index test Free swell index tests were performed according to the Egyptian Code 202-2006. The soils were oven dried at $105^{\circ}$ and then ground using a mortar and pestle until the soil passed the $0.02 \mathrm{~mm}$ standard sieve. $30 \mathrm{ml}$ of water was poured into a $100 \mathrm{ml}$ graduated cylinder. Ten grams of sieved soil was placed in the water in $1 \mathrm{~g}$ increments under free fall. After the $10 \mathrm{~g}$ was added, additional solution was poured to fill the cylinder to the $100 \mathrm{ml}$ and to rinse any particle of soil adhering to the internal sides of the cylinder. After minimum $24 \mathrm{~h}$ of hydration period after the last increment, the final volume of swollen soil was measured.

\subsubsection{Standard 1-D swelling test (Oedometer)}

Swelling in Oedometer tests was performed in a standard one dimensional Oedometer apparatus as per ASTM D 2435. The oven dried soil samples were compacted in a fixed stainless

Steel Oedometer ring with an internal diameter of $75 \mathrm{~mm}$. In the Oedometer cell, the swell under loading was performed to determine the swell percent at a seating load $12.5 \mathrm{KN} / \mathrm{m}^{2}$

Three samples were tested for each salt concentration sustained until the vertical movement has stopped. Water was then added to the cell and the swelling was recorded with time.

Sample (S1) was immersed in fresh water for one month under seating load of about 12.50 $\mathrm{KN} / \mathrm{m} 2$, with continues inundation to compensate for the absorption and evaporation processes in order to maintain the water level constant throughout the test period. The measured heave with time is plotted versus time .The measured soil heave is about $5.61 \mathrm{~mm}$.

A summary of the engineering properties of the natural soil is shown in Table 2. The soil is classified as silty clay of high plasticity $(\mathrm{CH})$ in accordance with Unified Soil Classification System, (USCS).

Table 2 Physical properties of selected expansive soil sample

\begin{tabular}{|l|l|}
\hline Property & Value \\
\hline Specific gravity (Gs) & 2.63 \\
\hline Natural water moisture, \% & 8.56 \\
\hline Bulk Density KN/m ${ }^{3}$ & 2.02 \\
\hline Liquid limit (LL), \% & 91.1 \\
\hline Plastic limit (PL), \% & 30.4 \\
\hline Plasticity index (PI), \% & 60.7 \\
\hline Optimum moisture Content, \% & 16.5 \\
\hline Maximum dry density, KN/m ${ }^{3}$ & 17.83 \\
\hline Free swell index (FSI), \% & 66.65 \\
\hline Swelling heave (mm) & 5.61 \\
\hline
\end{tabular}

\section{RESULTS AND DISCUSSION}

A systematic experimental program was undertaken to observe the variation in Atterberg limits and optimum moisture content and maximum dry densities. For this Atterberg Limits test and standard proctor test have been conducted as per international standards and respective curves were plotted to determine the Optimum Moisture Content and corresponding Maximum Dry 
Density for cohesive soil .results show the effect and extent of reduction on treatment of common salt on the engineering properties of studied expansive soil.

\subsection{Effect on Chemical Properties}

X-ray Diffraction (XRD) and differential thermal analysis tests are performed to allow identifying the type of minerals present in the clay soil. Understanding and interpretation of the diffraction patterns are based on the fact that each crystalline material has its own characteristic atomic structure which diffracts X-ray in a characteristic pattern. Also, the heat of the thermal reaction is proportional to the amount of thermally active material in the sample.

The effect of salt concentration on chemical composition was shown in Table 3. Table shows that there is a remarkable change in oxide contents of soils when tested with salt water. Table shows that there is a remarkable change in oxide contents of soils when tested with salt water.

Table 3 XRF analysis of natural and treated fine grained soil

\begin{tabular}{|c|c|c|c|c|c|c|c|c|c|c|c|c|c|c|c|c|c|c|c|}
\hline & $\begin{array}{l}\mathrm{Si} \\
\mathrm{O} \\
2\end{array}$ & $\begin{array}{l}\mathrm{AL} \\
2 \mathrm{O} \\
3\end{array}$ & $\begin{array}{l}\mathrm{Fe} \\
2 \mathrm{O} \\
3\end{array}$ & $\begin{array}{l}\mathrm{C} \\
\mathrm{a} \\
\mathrm{O}\end{array}$ & $\begin{array}{l}\mathrm{M} \\
\mathrm{g} \\
\mathrm{O}\end{array}$ & $\begin{array}{l}\mathrm{Na} \\
2 \\
\mathrm{O}\end{array}$ & $\begin{array}{l}\mathrm{K} \\
2 \\
\mathrm{O}\end{array}$ & $\begin{array}{l}\mathrm{S} \\
\mathrm{O} \\
3\end{array}$ & $\begin{array}{l}\mathrm{Ti} \\
\mathrm{O} \\
2\end{array}$ & $\begin{array}{l}\mathrm{P} 2 \\
\mathrm{O} \\
5\end{array}$ & $\begin{array}{l}\mathrm{M} \\
\mathrm{N} \\
\mathrm{O}\end{array}$ & $\begin{array}{l}\mathrm{Zr} \\
\mathrm{O} \\
2\end{array}$ & $\begin{array}{l}\mathrm{S} \\
\mathrm{r} \\
\mathrm{O}\end{array}$ & $\begin{array}{l}\mathrm{Z} \\
\mathrm{n} \\
\mathrm{O}\end{array}$ & $\begin{array}{l}\mathrm{Cr} \\
2 \mathrm{O} \\
3\end{array}$ & $\begin{array}{l}\mathrm{B} \\
\mathrm{a} \\
\mathrm{O}\end{array}$ & $\begin{array}{l}\mathrm{C} \\
\mathrm{L}\end{array}$ & $\begin{array}{l}\text { L. } \\
\text { O. } \\
\text { L }\end{array}$ & $\begin{array}{l}\mathrm{T} \\
\text { ot } \\
\text { al }\end{array}$ \\
\hline Natural Soil & $\begin{array}{l}52 \\
.9\end{array}$ & $\begin{array}{l}17 . \\
7\end{array}$ & $\begin{array}{l}10 . \\
6\end{array}$ & $\begin{array}{l}2 . \\
0 \\
9\end{array}$ & $\begin{array}{l}1 . \\
5\end{array}$ & $\begin{array}{l}0 . \\
91\end{array}$ & $\begin{array}{l}1 . \\
9 \\
5\end{array}$ & $\begin{array}{l}1 . \\
3 \\
8\end{array}$ & $\begin{array}{l}1 . \\
53\end{array}$ & $\begin{array}{l}0 . \\
22\end{array}$ & - & $\begin{array}{l}0 . \\
08\end{array}$ & $\begin{array}{l}0 . \\
0 \\
5\end{array}$ & $\begin{array}{l}0 . \\
0 \\
4\end{array}$ & $\begin{array}{l}0.0 \\
4\end{array}$ & $\begin{array}{l}0 . \\
0 \\
4\end{array}$ & $\begin{array}{l}0 . \\
5 \\
5\end{array}$ & $\begin{array}{l}8 . \\
41\end{array}$ & $\begin{array}{l}99 \\
9 \\
9\end{array}$ \\
\hline $\begin{array}{l}\text { Soil mixed } \\
\text { with Salt Nacl } \\
5 \%\end{array}$ & $\begin{array}{l}52 \\
.1\end{array}$ & $\begin{array}{l}17 . \\
8\end{array}$ & $\begin{array}{l}9.0 \\
6\end{array}$ & $\begin{array}{l}1 . \\
7 \\
3\end{array}$ & $\begin{array}{l}1 . \\
52\end{array}$ & $\begin{array}{l}1 . \\
85\end{array}$ & $\begin{array}{l}1 . \\
6 \\
6\end{array}$ & $\begin{array}{l}1 . \\
0 \\
9\end{array}$ & $\begin{array}{l}1 . \\
49\end{array}$ & $\begin{array}{l}0 . \\
19\end{array}$ & - & $\begin{array}{l}0 . \\
07\end{array}$ & $\begin{array}{l}0 . \\
0 \\
4\end{array}$ & $\begin{array}{l}0 . \\
0 \\
4\end{array}$ & - & $\begin{array}{l}0 . \\
0 \\
4\end{array}$ & $\begin{array}{l}1 . \\
6 \\
3\end{array}$ & $\begin{array}{l}9 . \\
59\end{array}$ & $\begin{array}{l}99 \\
.9\end{array}$ \\
\hline $\begin{array}{l}\text { Soil mixed } \\
\text { with Salt Nacl } \\
10 \%\end{array}$ & $\begin{array}{l}51 \\
.2\end{array}$ & $\begin{array}{l}17 . \\
4\end{array}$ & $\begin{array}{l}9.6 \\
8\end{array}$ & $\begin{array}{l}1 . \\
9 \\
1\end{array}$ & $\begin{array}{l}1 . \\
44\end{array}$ & $\begin{array}{l}1 . \\
85\end{array}$ & $\begin{array}{l}1 . \\
8 \\
1\end{array}$ & $\begin{array}{l}1 . \\
1 \\
5\end{array}$ & $\begin{array}{l}1 . \\
53\end{array}$ & $\begin{array}{l}0 . \\
2\end{array}$ & - & $\begin{array}{l}0 . \\
07\end{array}$ & $\begin{array}{l}0 . \\
0 \\
5\end{array}$ & $\begin{array}{l}0 . \\
0 \\
4\end{array}$ & - & $\begin{array}{l}0 . \\
0 \\
2\end{array}$ & $\begin{array}{l}1 . \\
8 \\
4\end{array}$ & $\begin{array}{l}9 . \\
74\end{array}$ & $\begin{array}{l}99 \\
.9 \\
3\end{array}$ \\
\hline $\begin{array}{l}\text { Soil mixed } \\
\text { with Salt Nacl } \\
30 \%\end{array}$ & $\begin{array}{l}49 \\
.2\end{array}$ & $\begin{array}{l}16 . \\
8\end{array}$ & $\begin{array}{l}8.9 \\
9\end{array}$ & $\begin{array}{l}1 . \\
7\end{array}$ & $\begin{array}{l}1 . \\
42\end{array}$ & 3 & $\begin{array}{l}1 . \\
5 \\
5\end{array}$ & $\begin{array}{l}0 . \\
9 \\
8\end{array}$ & $\begin{array}{l}1 . \\
39\end{array}$ & $\begin{array}{l}0 . \\
18\end{array}$ & & $\begin{array}{l}0 . \\
07\end{array}$ & $\begin{array}{l}0 . \\
0 \\
4\end{array}$ & $\begin{array}{l}0 . \\
0 \\
2\end{array}$ & - & - & $\begin{array}{l}3 . \\
3 \\
6\end{array}$ & $\begin{array}{l}11 \\
.3\end{array}$ & $\begin{array}{l}10 \\
0\end{array}$ \\
\hline $\begin{array}{l}\text { Soil mixed } \\
\text { with Salt Nacl } \\
60 \%\end{array}$ & $\begin{array}{l}47 \\
.7\end{array}$ & $\begin{array}{l}16 . \\
5\end{array}$ & $\begin{array}{l}8.7 \\
6\end{array}$ & $\begin{array}{l}2 . \\
2 \\
8\end{array}$ & $\begin{array}{l}1 . \\
48\end{array}$ & $\begin{array}{l}3 . \\
28\end{array}$ & $\begin{array}{l}1 . \\
5 \\
8\end{array}$ & $\begin{array}{l}1 . \\
2 \\
5\end{array}$ & $\begin{array}{l}1 . \\
43\end{array}$ & $\begin{array}{l}0 . \\
18\end{array}$ & $\begin{array}{l}0 . \\
04\end{array}$ & $\begin{array}{l}0 . \\
07\end{array}$ & $\begin{array}{l}0 . \\
0 \\
4\end{array}$ & $\begin{array}{l}0 . \\
0 \\
4\end{array}$ & - & - & $\begin{array}{l}3 . \\
6 \\
4\end{array}$ & $\begin{array}{l}11 \\
.7\end{array}$ & $\begin{array}{l}99 \\
.9 \\
6\end{array}$ \\
\hline
\end{tabular}

Charts of X-ray diffraction and thermal differential analysis for soil sample mixed with $5 \%$ and $30 \%$ of salt concentration are shown in figures 3, 4, 5 and 6. Three major categories of reactions expected in the process of mixing a stabilizer with soil are: (i) the dehydration process, (ii) the ion exchange or flocculation, and (iii) the pozzolanic reaction .In the dehydration process, water in the mixture is consumed by the stabilizer and as a result calcium hydroxide, $\mathrm{CA}(\mathrm{OH}) 2$, is produced. Dissociation of calcium hydroxide in water increases the electrolytic concentration and $\mathrm{pH}$ of the pore water, which results in $\mathrm{Ca}$ cations being attracted to the negatively charged (anion) clay particles resulting in bonding between them and forming salt crystals in pores soil and role playing as cement. 


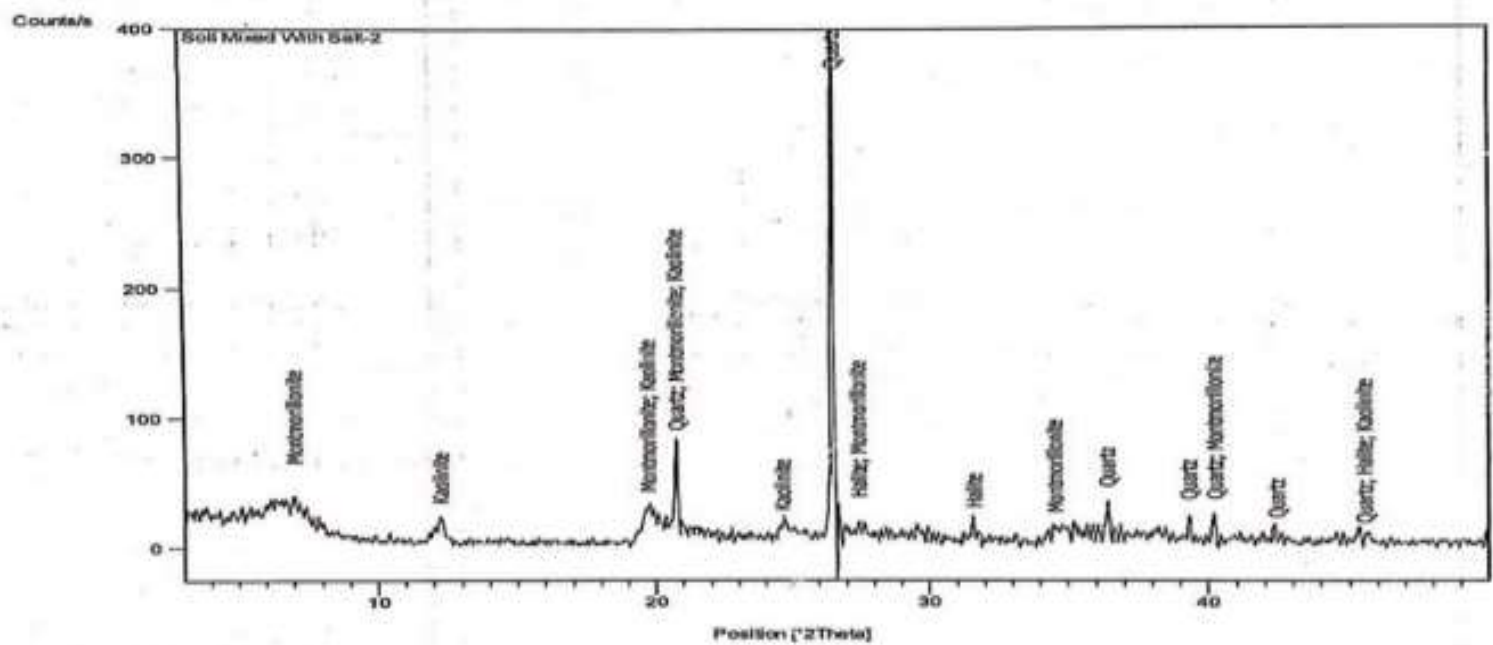

Figure $3 \mathrm{X}$-Ray diffraction for soil mixed with $5 \% \mathrm{NaCl}$

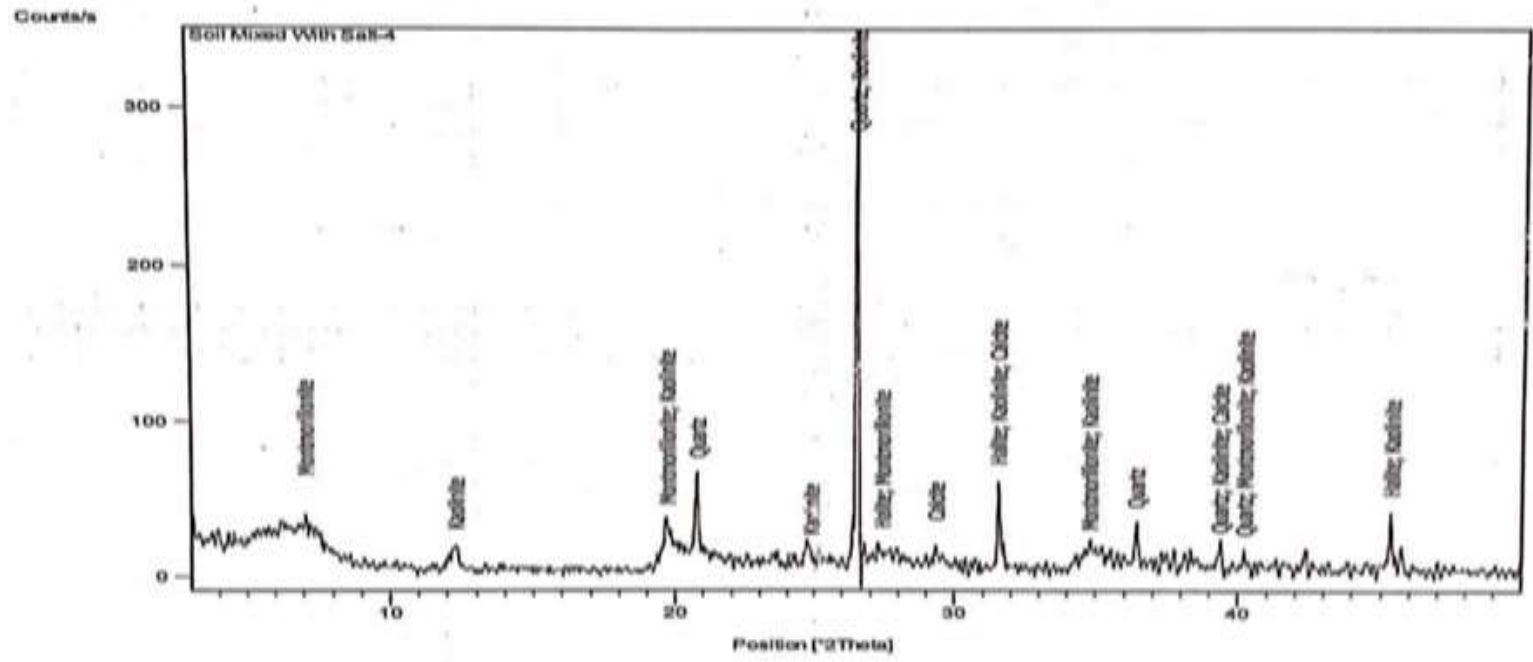

Figure $4 \mathbf{X}$-Ray diffraction for soil mixed with $30 \% \mathrm{NaCl}$

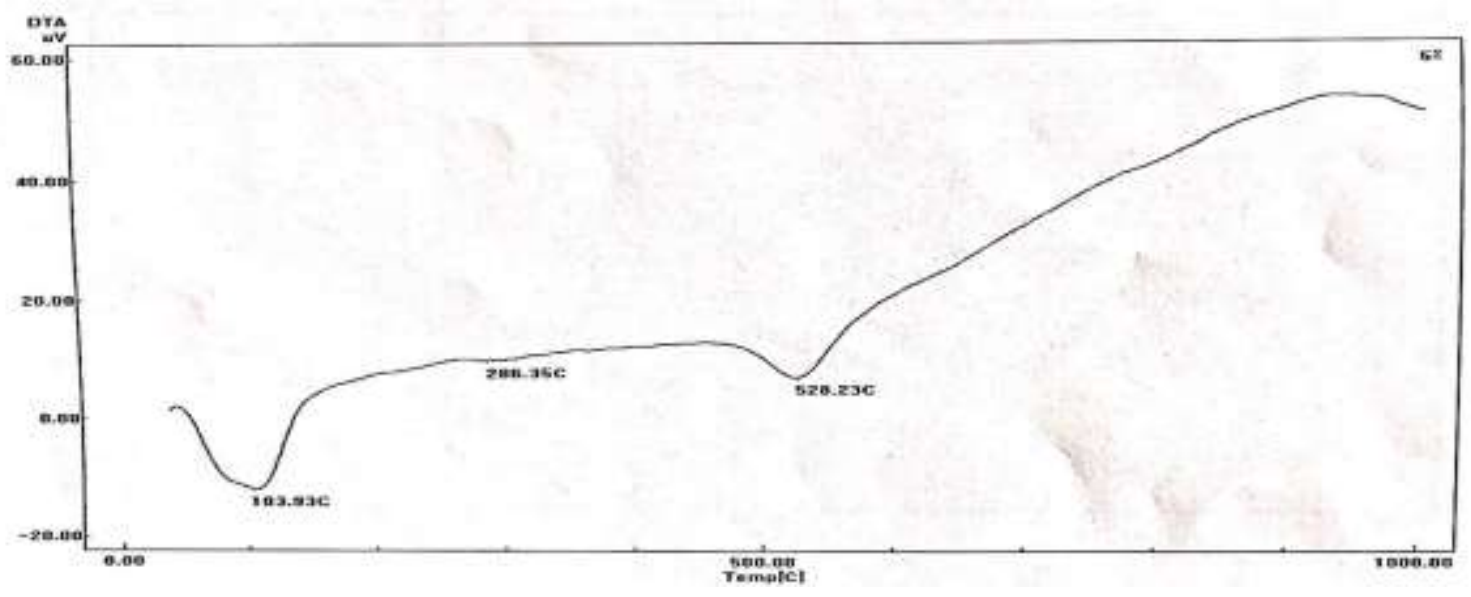

Figure 5 Differential thermal analysis (DTA) or soil mixed with $5 \% \mathrm{NaCl}$ 


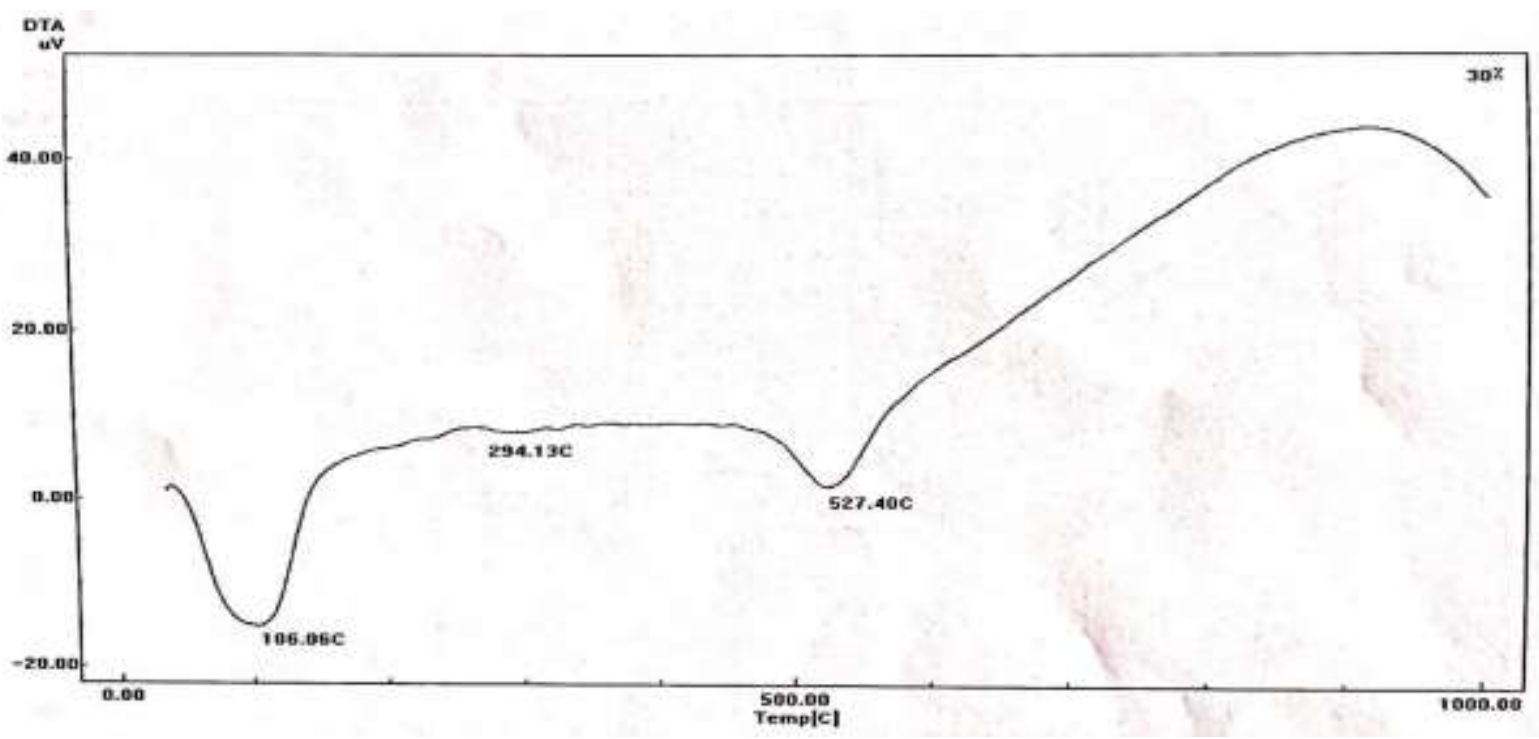

Figure 6 Differential thermal analysis (DTA) for soil mixed with $30 \% \mathrm{NaCl}$

Three major categories of reactions expected in the process of mixing a stabilizer with soil are: (i) the dehydration process, (ii) the ion exchange or flocculation, and (iii) the pozzolanic reaction. In the dehydration process, water in the mixture is consumed by the stabilizer and as a result calcium hydroxide, $\mathrm{Ca}(\mathrm{OH}) 2$, is produced. Dissociation of calcium hydroxide in water increases the electrolytic concentration and $\mathrm{pH}$ of the pore water, which results in Ca cations being attracted to the negatively charged (anion) clay particles resulting in flocculation of the clay particles.

\subsection{Effect on Atterberg's Limits}

The influence of each salt concentration on liquid limit and plastic limit are clearly shown in Fig. 6 and 7. From these figures, there is significant decrease in liquid limit and plastic limit. With the addition of salt water to the soil. The liquid limit has decreased by 43.5 percent with saline water. Due to reduce of liquid limit with increase in salinity water, plastic index also has decreased to a significant value.The test results are given in Table $\mathbf{4}$ and observed that there is remarkable salt water effect on tested consistency limits.

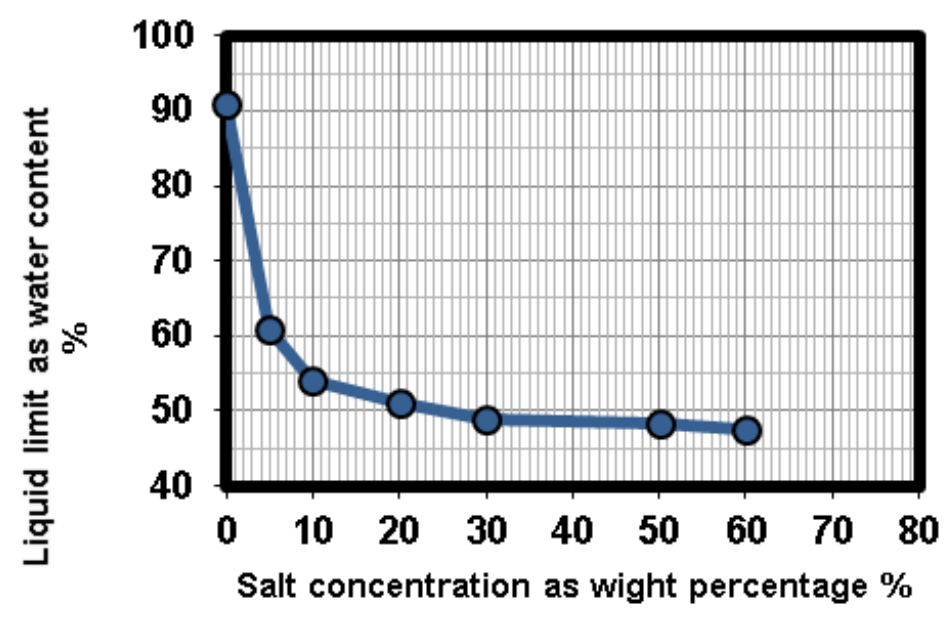

Figure 7 Influence of saltwater on Liquid Limit 


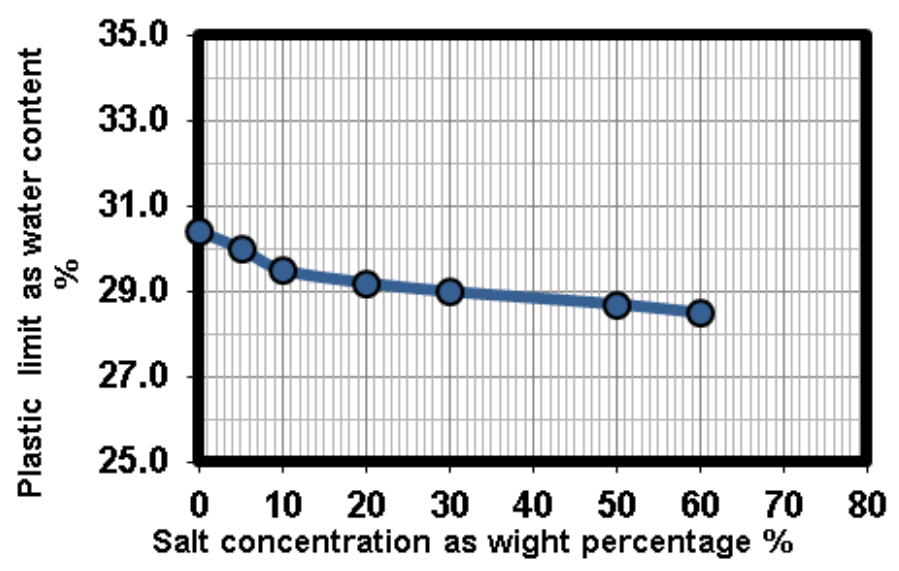

Figure 8 Influence of saltwater on Plastic Limit.

Table 4 Reduction \% of Atterberg Limits for TreatedSoil Samples

\begin{tabular}{|c|c|c|c|c|c|c|c|c|}
\hline \multirow{2}{*}{ Studied Property } & & \multicolumn{7}{|c|}{$\mathrm{NaCl}$ Concentration } \\
\hline & & $\begin{array}{l}\text { Fresh } \\
\text { Water }\end{array}$ & $5 \%$ & $10 \%$ & $20 \%$ & $30 \%$ & $50 \%$ & $60 \%$ \\
\hline \multirow{2}{*}{ Liquid limit } & $\%$ & \multirow{2}{*}{91.1} & 61.3 & 54.2 & 51 & 49.4 & 48.5 & 47.6 \\
\hline & Reduction \% & & (-) 32.7 & (-) 40.5 & $(-) 44.0$ & (-) 45.7 & (-) 46.7 & (-) 47.8 \\
\hline \multirow{2}{*}{ Plastic limit } & $\%$ & \multirow{2}{*}{30.4} & 30.0 & 29.5 & 29.2 & 29.0 & 28.7 & 28.5 \\
\hline & Reduction \% & & (-) 1.0 & (-) 2.9 & (-) 3.9 & (-) 4.6 & (-) 5.6 & $(-) 6.2$ \\
\hline \multirow{2}{*}{ Plasticity index } & $\%$ & \multirow{2}{*}{60.7} & 31.3 & 24.7 & 21.8 & 20.4 & 19.8 & 19.1 \\
\hline & Reduction \% & & (-) 48.4 & (-) 59.3 & $(-) 64.0$ & (-) 66.4 & (-) 67.3 & (-) 68.5 \\
\hline
\end{tabular}

\subsection{Effect on Compaction Properties}

To observe the effect of salt water on compaction characteristics of clayey soil, Light compaction Proctor test has been done on both tap water and salt water as per international standards. The dry density vs. Moisture Content Curve for both tap water and different concentration of salt water is shown in Fig. 9, 10 and 11. The test results of compaction test are also given in Table $\mathbf{5}$ and found that there is remarkable change in compaction characteristics of soils when tested with salt water. Maximum dry density of clayey soil increases in presence of sea water on comparing with results obtained from tap water. On the other hand, Optimum Moisture Content of clayey soil decreases in case of salt water 
Evaluation Of Salt Water Effect On The Physical Properties and Compaction Characteristics Of Expansive Soil

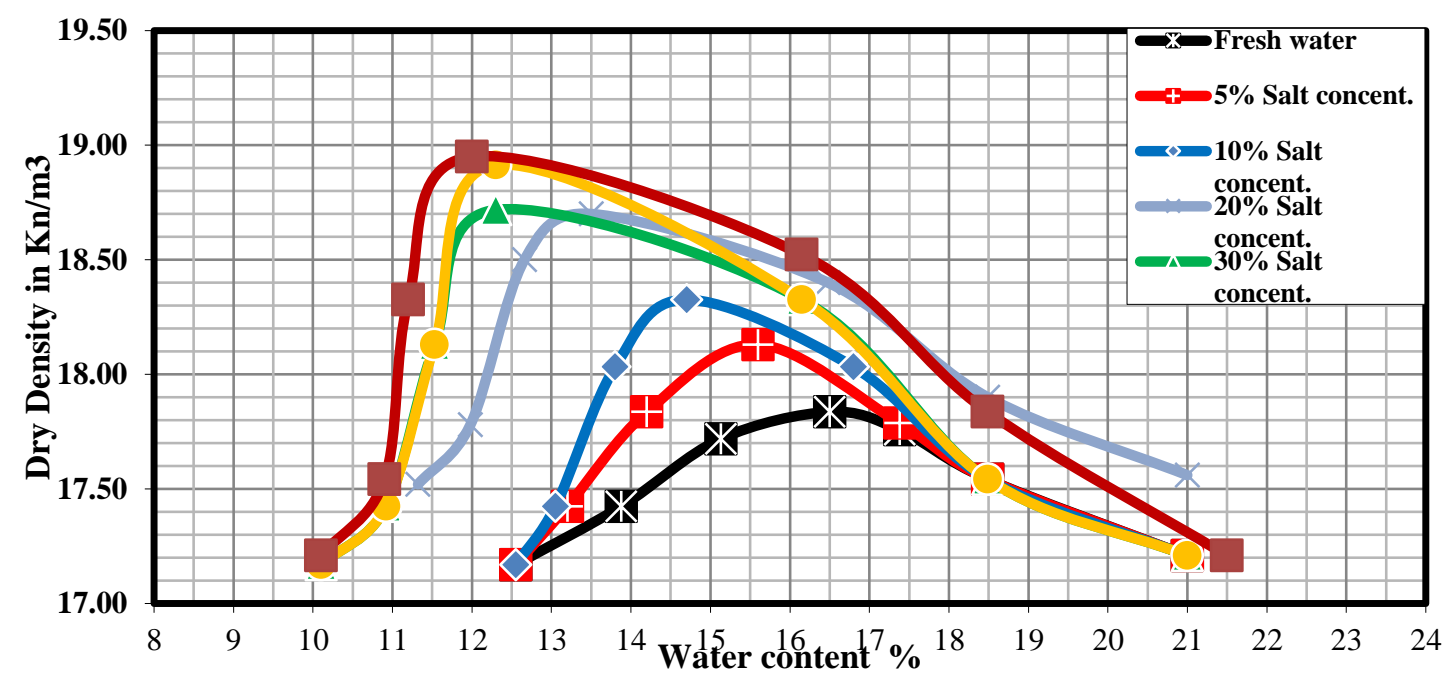

Figure 9 Influence of saltwater on Compaction Properties

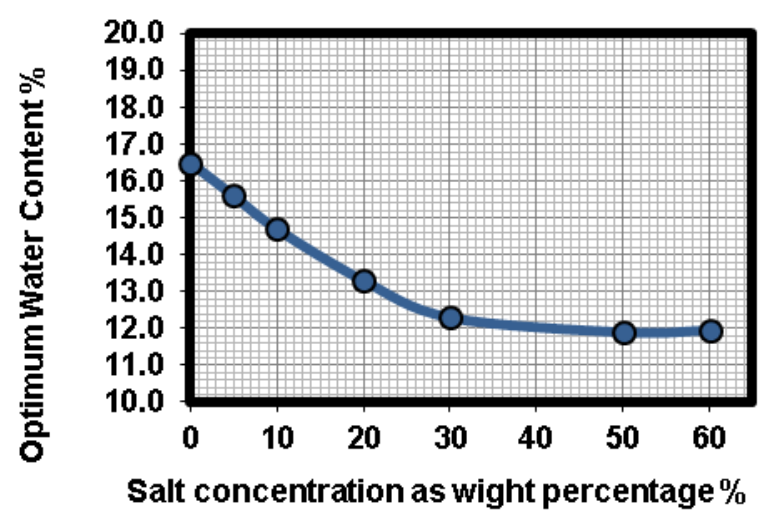

Figure 10 Influence of saltwater on Optimum Water Content

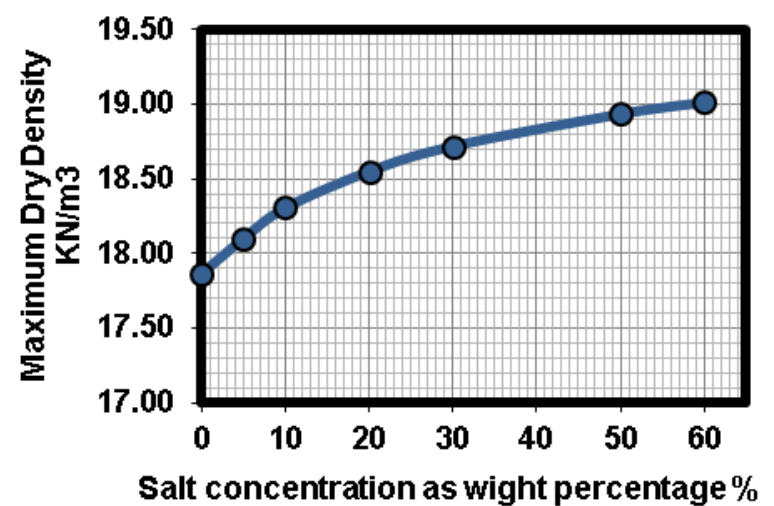

Figure 11 Influence of saltwater on Max. Dry Density 
Table 5 Change \% of Compaction Properties for Treated Soil

\begin{tabular}{|c|c|c|c|c|c|c|c|c|}
\hline \multirow{2}{*}{\multicolumn{2}{|c|}{ Studied Property }} & \multirow[b]{2}{*}{ Fresh Water } & \multicolumn{6}{|c|}{$\mathrm{NaCl}$ Concentration } \\
\hline & & & \multirow{2}{*}{$\frac{5 \%}{15.6}$} & \multirow{2}{*}{$\frac{10 \%}{14.7}$} & \multirow{2}{*}{$\frac{20 \%}{13.5}$} & \multirow{2}{*}{$\frac{30 \%}{12.3}$} & \multirow{2}{*}{$\frac{50 \%}{12.3}$} & \multirow{2}{*}{\begin{tabular}{|l|}
$60 \%$ \\
12.0
\end{tabular}} \\
\hline Optimum & $\%$ & & & & & & & \\
\hline $\begin{array}{l}\text { Moisture } \\
\text { Content }\end{array}$ & Change $\%$ & 16.5 & (-) 5.4 & (-) 10.9 & $(-) 18.2$ & (-) 25.4 & (-) 25.4 & (-) 27.2 \\
\hline \multirow{2}{*}{$\begin{array}{l}\text { Maximum Dry } \\
\text { Density }\end{array}$} & $\mathrm{KN} / \mathrm{m}^{3}$ & \multirow{2}{*}{17.83} & 18.13 & 18.32 & 18.7 & 18.71 & 18.91 & 18.95 \\
\hline & Change $\%$ & & (+) 1.7 & (+) 2.7 & (+) 4.8 & (+) 4.9 & $(+) 6.1$ & (+) 6.3 \\
\hline
\end{tabular}

\subsection{Effect on Free Swell Index}

The free swell index (FSI) of the treated clay with addition of 5\%, 10\%, 30\%, $50 \%$ and $60 \%$ of chloride salt is presented in Fig 11. In this figure, it is observed that the FSI value of the treated soil rapidly decreased with addition of $5 \%$ salt, beyond this percentage the FSI value marginally decreased. As shown in table 6, the reductions in FSI are 3.43\%, 6.75\%, $14.45 \%$, 11.95 and $9.85 \%$ respectively. These reductions may be due to the fact that at higher salt content, cation concentration increases which resulted in depressed double layer thickness due to cation exchange reaction.

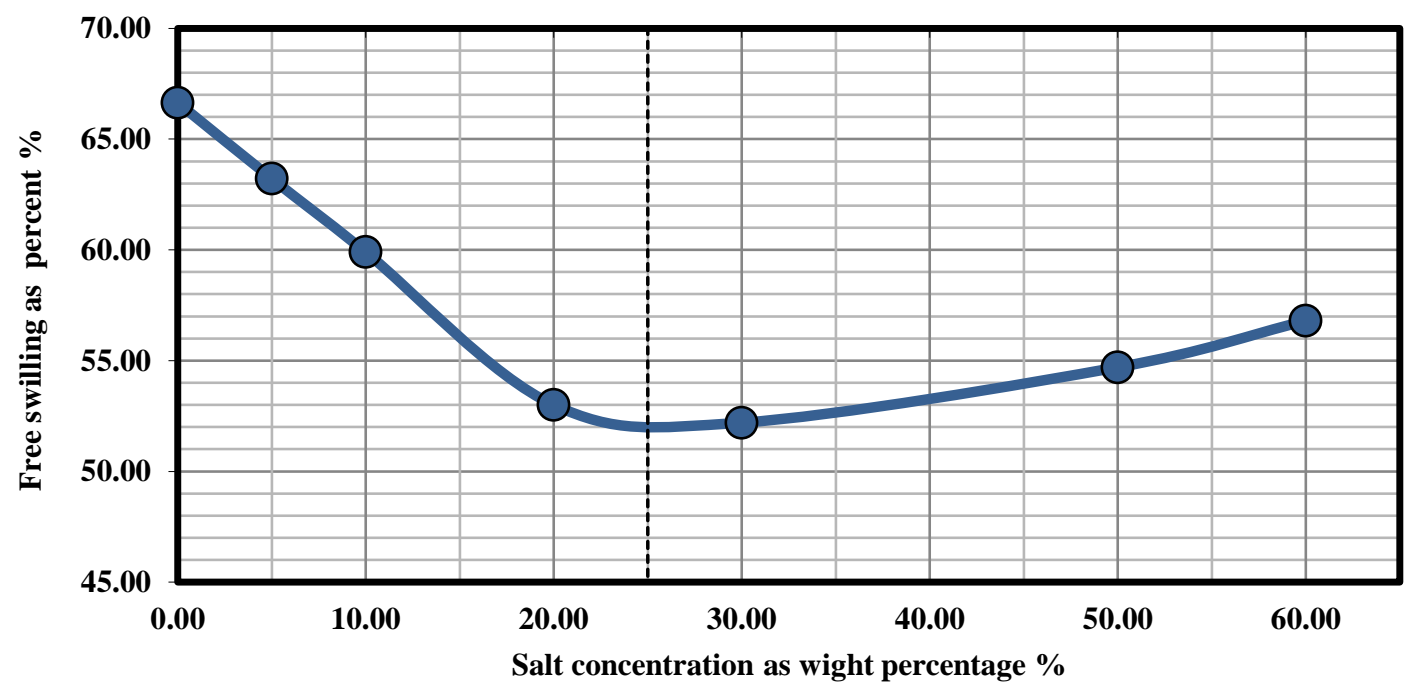

Figure 12 Influence of saltwater on free swell index

Table 6 Reduction \% of Free Swell for Treated Soil

\begin{tabular}{|c|c|c|c|c|c|c|c|c|}
\hline \multirow{2}{*}{\multicolumn{2}{|c|}{ Studied Property }} & \multicolumn{7}{|c|}{$\mathrm{NaCl}$ Concentration } \\
\hline & & $\begin{array}{l}\text { Fresh } \\
\text { Water }\end{array}$ & $5 \%$ & $10 \%$ & $20 \%$ & $30 \%$ & $50 \%$ & $60 \%$ \\
\hline \multirow{2}{*}{ Free swell } & $\%$ & \multirow{2}{*}{66.65} & 63.22 & 59.9 & 53 & 52.2 & 54.7 & 56.8 \\
\hline & Reduction \% & & (-) 5.1 & (-) 10.1 & $(-) 20.5$ & (-) 21.7 & (-) 17.9 & (-) 14.7 \\
\hline
\end{tabular}




\subsection{Effect on Swelling Properties (one-dimensional Oedometer Test):}

The swell percent variation with the surcharge loads was drawn to determine the swell pressure (i.e. the surcharge pressure at zero swell) with continues inundation to compensate for the absorption and evaporation processes in order to maintain the water level constant throughout the test period.. The swell heave at a seating load of about $12.50 \mathrm{KN} / \mathrm{m} 2$ is plotted versus time as for natural soil mixed with different salt concentration as shown in Fig. 12.The measured soil heave is about $5.61 \mathrm{~mm}$.as shown in Figure 13. Table 7, shows the reductions in swelling heave has increased and a significant negative effect on soil behavior was observed for salt concentration higher than $25 \%$.

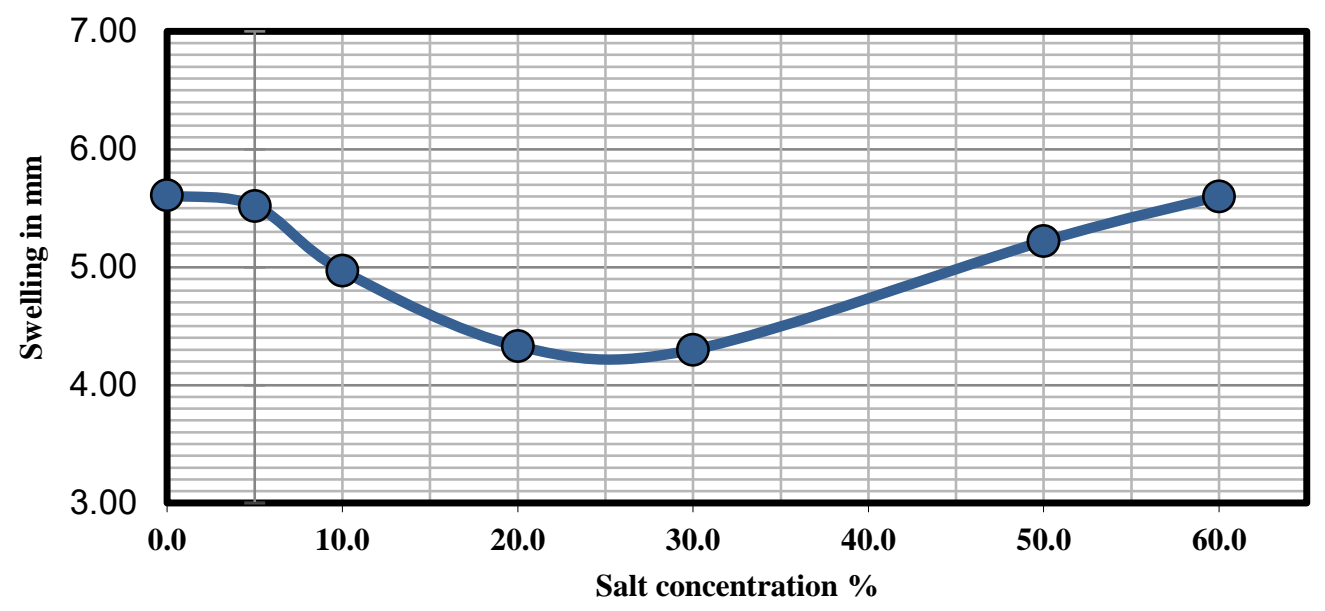

Figure 13 Influence of saltwater on Swelling Heave

Table 7 Reduction \% of Swelling Heave for Treated Soil

\begin{tabular}{|l|l|l|l|l|l|l|l|l|}
\hline \multirow{2}{*}{ Studied Property } & \multicolumn{6}{|c|}{ NaCl Concentration } \\
\cline { 3 - 11 } & & $\begin{array}{l}\text { Fresh } \\
\text { Water }\end{array}$ & $5 \%$ & $10 \%$ & $20 \%$ & $30 \%$ & $50 \%$ & $60 \%$ \\
\hline \multirow{3}{*}{ Swelling Heave } & $\mathrm{mm}$ & 5.61 & 5.52 & 4.97 & 4.33 & 4.3 & 5.22 & 5.6 \\
\cline { 2 - 11 } & Reduction \% & & $(-) 1.6$ & $(-) 11.4$ & $(-) 22.8$ & $(-) 23.4$ & $(-) 6.95$ & $(-) 0.18$ \\
\hline
\end{tabular}

This decrease in the aggregate swelling with increasing $\mathrm{NaCl}$ concentration is due to the compression of the diffuse double layer as a result of increasing the ion concentration, resulting in removing some silica, and so alumina became available for reaction with the salt solution. And thus attractive force between soil particles increase, establishing bonding between them, finally allowing for decrease in the swelling properties of clay soil.

\section{FUTURE STUDIES}

Future studies on different soil types are recommended to study the effect of addition of saline water with varying mixing ratios. Special attention should be paid on using experimental model to study enhancing of footing resting on swelling soil when using salt water as a chemical stabilizer. 


\section{CONCLUSION}

Finally, from the above discussion, it is clear that there is a considerable improvement in the plasticity and swelling properties of expansive soil treated with NaCL. In this study investigations of the effects of salt water as a chemical stabilizer in the geotechnical behavior of clayey soil was carried out. On the basis of systemic experimental investigation on physical, Chemical and mechanical properties of cohesive soil, the following conclusions can be drawn:

- Atterberg's Limits such as Liquid Limit decreases by $47.8 \%$ in presence of salt water. Further, plasticity index also decreases by $68.5 \%$ due increase in salinity in water to $60 \%$ salt concentration. The decrease in Atterberg's limit is due to higher cation valance and increasing salt concentration.

- Maximum dry density of clayey soil increases from $17.83 \mathrm{KN} / \mathrm{m} 3$ to 18.95 in presence of salt water comparing with the results obtained from tap water.

- Optimum Moisture Content of clayey soil decreases from $16.5 \%$ to $12 \%$ in case of Salt water.

- Increase in concentration of salt water above $25 \%$ will not cause a significant difference in soil behavior.

- Consolidation test showed decrease in swelling values from 5.61 for to $4.3 \mathrm{~mm}$ in swelling heave, and a decrease of $21.7 \%$ in free swell index. A significant negative effect on soil behavior was observed for salt concentration higher than $25 \%$.

\section{ACKNOWLEDGEMENTS}

The experimental work of this study was carried out at the Soil Mechanics Laboratory of civil Eng. Department, Al-Azhar University, thanks for the laboratory staff and technicians, and also for the help of material lab technicians.

\section{REFERENCES}

[1] Abood T.A., Kasa A.B., Chik Z.B. (2007). Stabilization of Silty Clay Soil Using Chloride Compounds. Journal of Engineering Science and Technology Vol. 2, No. 1 102-110

[2] Alamdar, S. S.,"Long time Effect of Saline Water on Clay," M.Sc Thesis, Faculty of Engineering, TarbiatModares University. (In Pertioan).,1999.

[3] Arasan, S., and T. Yetimoglu. "Effect of Inorganic Salt Solutions on the Consistency Limits of Two Clays,” Turkish J. Eng. Env. Sci, 32, 107- 115. 2008.

[4] Arora, A. P. S, Das K., Sengupta D., and Maity J. (2018). "Effect of Sea Water on the Geotechnical Properties of Cohesive Soil". International Research Journal of Engineering and Technology (IRJET), Volume: 05 Issue: 05 | May, pp.3003-3006.

[5] Arumairaj, P.D., and Sivajothi A., (2011), "Effect of Sea Water on Expansive Soils" EJGE, Vol. 15 [2011], Bund. J, pp. 425-43

[6] Ayininuola, G. M., O. A., Agbede and S. O. Franklin., "Influence of Calcium Sulphate on Subsoil Cohesion and Angle of Friction," Journal of Applied Sciences Research, 5, 297-304, 2009.

[7] Chattopadhyay, p. K., "Residual Shear Strenght of Some Pure Clay Mineral," Ph.D. Dissertation, Department of Civil Engineering of Alberta.Edmonton, 1972 
[8] Chen, F. H. (1981) "Foundations on Expansive Soils", Elsevier Scientific Publishing Company,

[9] Di Maio, C., and G. b. Fenelli., "Residual Strenght of Kolin and Bentonit: The Influence of Their Constituent Pore Fluid," Geotecnique, 44, 2, 217-226, 1994.

[10] Durotoye, T.O, Akinmusuru, J.O, Ogbiye, A.S, Bamigboye, G.O (2016), Effect of Common Salt on the Engineering Properties of Expansive Soil, International Journal of Engineering and Technology Volume 6 No.7, July, PP.233-241

[11] Erdal Cockca (1999) "Effect of Fly Ash on Swell Pressure of an Expansive Soil" Electronic Journal of Geotechnical Engineering (EJGE).

[12] Hegazy, Y.A., "Swelling Behavior and Some Treatment Methods of Expansive Soil Beneath Shallow Foundations", M. Sc. Thesis, Faculty of Engineering, Cairo University, Egypt, 1993.

[13] Kumar, Bale Nikhil, Smitha, Jeevana, Uday, K.V, (2015). Effect of Salinity on Geotechnical Properties of Expansive Soils. International Journal of Innovative Research in Science, Engineering and Technology. Vol 4(7)

[14] Mahasneh, B. Z., "Dead Sea Water as a Soil Improvement Agent," Electronic Journal of Geotechnical Engineering, 9, 2004.

[15] MohieEldin Elmashad and Alaa A. Ata, (2014). "Effect of seawater on consistency, infiltration rate and swelling characteristics of montmorillonite clay". Housing and Building National Research Center HBRC Journal.

[16] Mowfy Y., G. Bauer, F. Saker, 2015 "Treatment of Expansive Soils: A Laboratory Study", Transportation Research Record 1032, Egypt.

[17] Naeini, S. A., and M. A. Jahanfar., "Effect of Salt Solution and Plasticity Index on Undrain Shear Strength of Clays," World Academy of Science Engineering and Technology, 73, 2011

[18] Otoko, G. R. (2014). "The Effect of Salt Water on the Physical Properties, Compaction Characteristics and Unconfined Compressive Strength of a Clay, Clayey Sand Aand Base Course", European International Journal of Science and Technology Vol. 3 No. 2 March, 2014.

[19] Ramadas, T.L., Kumar, N.D., and Yesuratnam, G., 2012. A study on strength and swelling characteristics of three expansive soils treated with $\mathrm{CaCl}$ 2. International Journal of Advances in Civil Engineering and Architecture. 1(1):77-86

[20] Rassoul Ajalloeian, HadisehMansouri, "Effect of Saline Water on Geotechnical Properties of Fine-grained Soil" Vol. 18 [2013], Bund. G, EJGE. (6)

[21] Shariatmadari, N., M. Salami and M. KarimpourFard (2011) "Effect of Inorganic Salt Solutions on Some Geotechnical Properties of Soil-Bentonite Mixtures as Barriers," International Journal of Civil Engineering, 9.

[22] Siddiqua, S., J. Blatz, G. Siemens, 2011. Evaluation of the impact of pore fluid chemistry on the hydro mechanical behavior of clay-based sealing materials. Canadian Geotechnical Journal, 48; 199-213.

[23] Tiwari, B. G., R. Tuladhar and H. Marui (2005) "Variation in Residual Shear Strength of the Soil with the Salinity of Pore Fluid," Journal of Geotechnical \&Geoenvironmental Engineering, 131. 
[24] Y. Yukselen-Aksoy, A. Kaya, A. O" ren, Seawater effect on consistency limits and compressibility characteristics of clays, J.Eng. Geol. 102 (2008) 54-61. (2)

[25] Yukselen-Aksoy, Y., A. Kaya and A. H. Ören (2008) "Seawater Effect on Consistency Limits and Compressibility Characteristics of Clays," Engineering Geology, 102, 54-61.

[26] Zumrawi M., A. Mahjoub, I. Alnour, "Effect of Some Chloride Salts on Swelling Properties of Expansive Soil", University of Khartoum, Sudan, 2017. 